University of Nebraska - Lincoln

DigitalCommons@University of Nebraska - Lincoln

USDA National Wildlife Research Center - Staff Publications
U.S. Department of Agriculture: Animal and Plant Health Inspection Service

3-1-2006

\title{
Influence of Fish Stocking Density on the Foraging Behavior of Double-crested Cormorants, Phalacrocorax auritus
}

\author{
Scott J. Werner \\ USDA-APHIS-Wildlife Services, scott.j.werner@aphis.usda.gov \\ Brian S. Dorr \\ USDA/APHIS/WS National Wildlife Research Center, brian.s.dorr@aphis.usda.gov
}

Follow this and additional works at: https://digitalcommons.unl.edu/icwdm_usdanwrc

Part of the Environmental Sciences Commons

Werner, Scott J. and Dorr, Brian S., "Influence of Fish Stocking Density on the Foraging Behavior of Doublecrested Cormorants, Phalacrocorax auritus" (2006). USDA National Wildlife Research Center - Staff Publications. 125.

https://digitalcommons.unl.edu/icwdm_usdanwrc/125

This Article is brought to you for free and open access by the U.S. Department of Agriculture: Animal and Plant Health Inspection Service at DigitalCommons@University of Nebraska - Lincoln. It has been accepted for inclusion in USDA National Wildlife Research Center - Staff Publications by an authorized administrator of DigitalCommons@University of Nebraska - Lincoln. 


\title{
Influence of Fish Stocking Density on the Foraging Behavior of Double-crested Cormorants, Phalacrocorax auritus
}

\author{
SCOTt J. WeRner 1.2 AND Brian S. DorR \\ United States Department of Agriculture, Animal and Plant Health Inspection Service, \\ Wildlife Services, National Wildlife Research Center, Mississippi Field Station, \\ Mississippi State Universiț; Mississippi 39762 USA
}

The abundance of double-crested cormorants (Phalacrocorax auritus; cormorants) wintering in the delta region of Mississippi has increased approximately $250 \%$ in the last decade (Glahn et al. 2000). The impacts of cormorants to southeastern catfish (Ictalurus punctatus) production have been investigated via pond-side observations (Stickley et al. 1992), radio telemetry (King et al. 1995; Dorr et al. 2004), food habits studies (Glahn et al. 1995), bioenergetic modeling (Glahn and Brugger 1995), and controlled experimentation (Glahn and Dorr 2002).

Glahn and Brugger (1995) considered the energetic requirements of cormorants, their relative abundance, and the state of the aquaculture industry (i.e., acreage and production) to predict the economic impact of cormorants on catfish aquaculture. These authors estimated that the cost of replacing the 18-20 million catfish fingerlings consumed by cormorants each year would be approximately $\$ 2$ million. Whereas cormorant wintering populations have increased since the early 1990s, Glahn et al. (2000) estimated that this replacement cost would be approximately $\$ 5$ million annually. Recent controlled foraging experiments have demonstrated the impacts of cormorants on gross (i.e., atharvest) catfish production (Glahn and Dorr 2002). Considering the value of catfish at harvest $(\sim 500 \%$ of the fingerling replacement cost), Glahn et al. (2002) suggested that the actual economic loss to southeastern catfish

\footnotetext{
1 Corresponding author.

2 Present address: United States Department of Agriculture, Animal and Plant Health Inspection Service. Wildlife Services, National Wildlife Research Center, 4101 LaPorte Avenue, Fort Collins, Colorado 80521 USA.
}

farmers (via cormorant predation) may approach $\$ 25$ million annually.

Glahn et al. (2002) also suggested that higher catfish stocking densities and decreased cormorant abundancc may mitigate cormorant impacts to catfish production. Several investigators have concluded that a positive relationship exists between cormorant fish consumption and the density of particular fishes in open waters in Europe (Dirksen et al. 1995; Richner 1995; Warke and Day 1995; Gremillet and Wilson 1999) and North America (Simmonds et al. 2000; Anderson et al. 2004). Similarly, Werner (2004) suggested that fish density within catfish aquaculture ponds may affect the foraging behavior and efficiency of American White Pelicans (Pelecanus erythrorhynchos) on these ponds.

This experiment was designed to evaluate the behavior of cormorants' foraging on experimental aquaculture ponds stocked at relatively high and low catfish densities. An understanding of food and habitat preferences, and the effect of agricultural practices (e.g., fish stocking density) on wildlife behavior may contribute to the development of cost-effective methods to minimize commodity losses. This study was part of the approved National Wildlife Research Center's Research Project entitled "Economic Impact and Management of Bird Predation at Aquaculture Facilities in the Southeastern United States."

\section{Methods}

In October 2001, we captured three doublecrested cormorants in western Mississippi using methods described by King et al. (1994). All cormorants were weighed to the nearest $0.01 \mathrm{~kg}$ (average $=2.09 \mathrm{~kg}$; range $=1.96-2.18 \mathrm{~kg}$ ) and marked with a unique leg band. Cormorants were 
randomly assigned and released on one of three 0.04-ha experimental aquaculture ponds (40$130 \mathrm{~cm}$ deep, $17 \mathrm{~m}$ wide, and $24 \mathrm{~m}$ long) within our 0.6-ha research aviary at Mississippi State University (Glahn and Dorr 2002; Werner 2004).

The experimental aquaculture ponds were divided in half via vertical, subsurface screening extended through the width of each pond. On October 2, 2001, one-half of each pond was stocked with 250 Channel Catfish fingerlings to simulate a stocking rate of approximately 12,355 fish/ha. The remaining pond halves were stocked with 1000 catfish fingerlings $(49,420 \mathrm{fish} / \mathrm{ha})$. Both pond halves were available to individual cormorants throughout foraging trials. The area surrounding each pond ( $\sim 0.2 \mathrm{ha}$ ) provided room for cormorants to access both pond halves via the ground or air. The assignment of fish density treatments was randomized between pond halves.

We weighed a sample of 50 catfish prior to stocking each pond half to estimate the mass $( \pm 1 \mathrm{~g})$ of stocked fish. We recorded daily the fish mortality observed (i.e., floating) on each pond. These records facilitated our estimation of fish consumption by cormorants in the absence of other fish mortality factors (e.g., fish disease, poor water quality). Water temperatures within experimental ponds ranged from 10.6 to $20.7 \mathrm{C}$ and from 9.0 to $20.2 \mathrm{C}$ during the October 2001 and March 2002 foraging trials, respectively. The length of catfish stocked during the first and second foraging trials (as predicted by mass; Pomerleau and Engle 2003) averaged $18 \mathrm{~cm}$ (range $=11-25 \mathrm{~cm})$ and $15 \mathrm{~cm}$ (range $=1 \mathrm{I}-22 \mathrm{~cm})$, respectively.

This study consisted of two 20-d foraging trials. Observations from a concealed tower were made for 50-min during each morning and afternoon for each cormorant. Observation schedules were randomized among birds for each day of the trial. Subsequent analyses provided estimates of foraging time $( \pm 1 \mathrm{~min}$ ), and the number of dives and fish captures observed during recorded foraging bouts. Foraging bouts were initiated by individual cormorants diving in experimental ponds during observation periods. The conclusion of a foraging bout was marked by a prolonged interval $(\geq 1 \mathrm{~min})$ between dives.
Subsequent to the first 20-d trial, the first group of three cormorants was removed from experimental ponds and fish within ponds were seined and counted. Ponds were then refilled with water and populated with new catfish fingerlings on February 26, 2002. In March 2002, three additional (experimentally naïve) double-crested cormorants were captured in southeastern Arkansas. These cormorants were randomly assigned and released within the aviary (one cormorant on each of the three test ponds) for the duration of the second trial. The second group of three cormorants was removed from experimental ponds, and fish within ponds were seined and counted at the conclusion of the second foraging trial.

A repeated-measures ANOVA was used to analyze differences in average foraging time, dives, fish captures, captures per foraging time, and captures per dives observed in low- and high-density ponds using SAS version 8 software (SAS Institute, Inc., Cary, NC, USA). Morning and afternoon foraging observations were pooled for these analyses. The independent variables of these analyses were fish density and the density-by-study day interaction. Tukey post hoc contrasts were used to separate these means of significant $(P \leq 0.05)$ ANOVA effects. A paired $t$-test was used to compare average fish consumption within high- and low-fish density pond halves following the foraging trial. Descriptive statistics (mean \pm SEM) were used to summarize the foraging behavior of cormorants during the study.

\section{Results}

Cormorants spent more time foraging on pond halves stocked with 1000 catfish $(49,420$ fish/ha) than on pond halves stocked with 250 catfish $\left(12,355 \mathrm{fish} / \mathrm{ha} ; \quad F_{1,5}=22.49\right.$, $P=0.005$ ) throughout the 20 -d foraging trial. Cormorants foraged on high- and low-fish density ponds an average of $132( \pm 10.1)$ and $73( \pm 10.3)$ sec during our 50-min observations, respectively. During that time, cormorants dove an average of three $( \pm 0.3)$ times on high-density ponds and two $( \pm 0.3)$ times on low-density ponds $\left(F_{1,5}=13.29, P=0.01\right)$.

Cormorants captured an average of 0.8 $( \pm 0.06)$ catfish on high-density ponds and 0.3 
$( \pm 0.05)$ catfish on low-density ponds $\left(F_{1.5}=48.42, P=0.001\right)$ during our 50-min foraging observations. A fish density-by-study day interaction existed among fish captures observed during the study $\left(F_{34,92}=1.61\right.$, $P=0.03$ ). Compared to fish captured within low-density ponds on Day 8, cormorants captured more fish within high-density ponds on Days $9,11,12,14$, and 18 of the foraging trial $(P<0.05$; Fig. 1). We observed no fish density-by-day interaction among recorded foraging times $\left(F_{3 \mathrm{x}, 92}=1.50, P=0.06\right)$ or dives $\left(F_{38.92}=1.00, P=0.48\right)$.

Foraging efficiency was also greater within pond halves stocked with 1000 catfish fingerlings (i.e., high stocking density). Relative to low-density pond halves, observed fish captures per foraging time were greater within highdensity halves $\left(F_{1,5}=36.01, P=0.002\right)$. Similarly, observed fish captures per dive were greater within high-density halves $\left(F_{1,5}=30.99\right.$, $P=0.003$ ). We observed no fish density-byday interaction among fish captures per foraging time $\left(F_{38.92}=1.44, P=0.08\right)$ or captures per dive $\left(F_{38,92}=1.48, P=0.07\right)$.

Cormorants consumed $60( \pm 15.2)$ and 161 $( \pm 25.7)$ catfish per bird within experimental aquaculture ponds stocked with 250 and 1000 fish, respectively, during the $20-\mathrm{d}$ foraging trial
(Table I). Thus, cormorants consumed more fish within pond halves associated with high fish densities than within low-density halves $\left(t_{5}=3.13, P=0.03\right)$. This consumption represents a total of $2.1 \mathrm{~kg}$ of catfish taken per bird within low-density ponds and $5.6 \mathrm{~kg}$ of catfish taken per bird from ponds stocked at relatively high fish densities (Table 1).

\section{Discussion}

All cormorants discriminated between pond halves stocked with 12,355 and $49,420 \mathrm{fish} / \mathrm{ha}$. When provided a choice between these relatively low and high fish densities, cormorants allocated more time and effort, and captured more catfish on pond halves stocked at relatively high densities. Interestingly, these preferences manifested subsequent to Day 6 of the 20-d foraging trials. An understanding of such foraging preferences and learning can be applied to reduce the impacts of fish-eating birds to aquacultural production.

On average, cormorants consumed $387 \mathrm{~g}$ of catfish fingerlings/bird per $d$ during the $20-d$ foraging trials (range $=264-607 \mathrm{~g} /$ bird per $\mathrm{d}$ ). Glahn and Brugger (1995) predicted that cormorants foraging at Mississippi catfish aquaculture facilities from November to March was 504 g/bird per $\mathrm{d}$, or $22 \%$ body mass

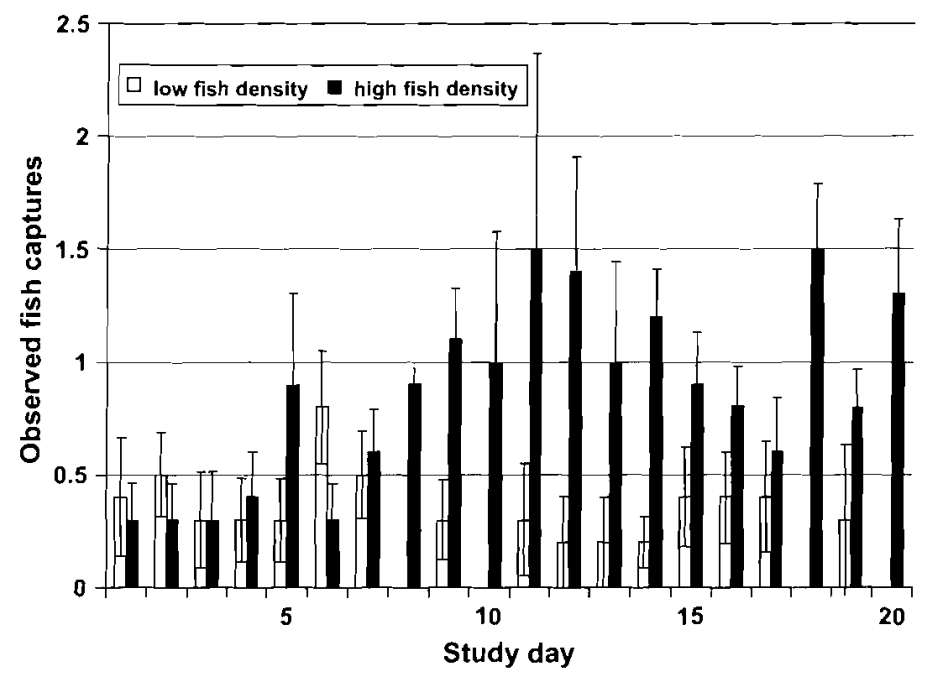

FIGURE I. Average ( \pm SEM) fish captures observed (during 50-min foraging obsenations) among double-crested cormorants $(N=6)$ foraging on experimental channel catfish aquaculture ponds stocked with 12.355 and 49,420 fish/ha. 
TABLE 1. Chamnel catfish consumption by double-cressed cormorams foraging on experimental aquaculture ponds. Cormorants $(N=6)$ were prese'n on pond halves stocked with 12,355 and 49,420 fisl/ha throughout a 20 -d foraging trial. Fish consumption was calculated based upon the number of fish stocked mimus (fish harlested and observed fish mortality\%.

\begin{tabular}{|c|c|c|c|c|c|c|c|}
\hline Pond & Date & Fish stocked & $\begin{array}{l}\text { Mean mass } \\
\text { per fish (g) }\end{array}$ & $\begin{array}{c}\text { Fish } \\
\text { harvested }\end{array}$ & $\begin{array}{c}\text { Observed fish } \\
\text { mortality }\end{array}$ & $\begin{array}{l}\text { Fish consumed } \\
\text { (per } 20 \mathrm{~d} \text { ) }\end{array}$ & $\begin{array}{l}\text { Fish mass consumed } \\
(\mathrm{kg} \text { per } 20 \mathrm{~d})\end{array}$ \\
\hline $1 \mathrm{~A}$ & October 2001 & 250 & 50 & 230 & 1 & 19 & 0.9 \\
\hline 1B & October 2001 & 1000 & 41 & 850 & 44 & 106 & 4.3 \\
\hline $2 \mathrm{~A}$ & October 2001 & 250 & 46 & 199 & 0 & 51 & 2.3 \\
\hline $2 \mathrm{~B}$ & October 2001 & 1000 & 48 & 776 & 21 & 203 & 9.8 \\
\hline $3 \mathrm{~A}$ & October 2001 & 1000 & 45 & 917 & 1 & 82 & 3.7 \\
\hline $3 \mathrm{~B}$ & October 2001 & 250 & 44 & 169 & 10 & 71 & 3.1 \\
\hline $1 \mathrm{~A}$ & March 2002 & 250 & 29 & 118 & 5 & 127 & 3.7 \\
\hline 1B & March 2002 & 1000 & 32 & 852 & 15 & 133 & 4.3 \\
\hline $2 \mathrm{~A}$ & March 2002 & 1000 & 28 & 804 & 1 & 195 & 5.5 \\
\hline $2 \mathrm{~B}$ & March 2002 & 250 & 26 & 208 & 4 & 38 & 1.0 \\
\hline $3 \mathrm{~A}$ & March 2002 & 1000 & 25 & 754 & 2 & 244 & 6.1 \\
\hline 3B & March 2002 & 250 & 30 & 187 & 9 & 54 & 1.6 \\
\hline \multirow{2}{*}{\multicolumn{2}{|c|}{ Average \pm SEM }} & & & & Low fish density & $60 \pm 15.2$ & $2.1 \pm 0.46$ \\
\hline & & & & & High fish density & $161 \pm 25.7$ & $5.6 \pm 0.91$ \\
\hline
\end{tabular}

(range $=449-551 \mathrm{~g} /$ bird per $\mathrm{d}$ ), thus energy requirements are likely greater under field conditions relative to those associated with our captive experiment.

Although yields can be maximized at relatively high catfish stocking densities (e.g., 30,000 fingerlings/ha: Losinger et al. 2000), bird depredation and other production constraints (e.g., feed cost, fish disease. water quality) may restrict the stocking density associated with maximized profits. Glahn and Dorr (2002) observed a $23 \%$ at-harvest production loss in experimental ponds stocked with 12,355 catfish/ha and 500 cormorant d/ha. Estimated gross production losses in ponds stocked with 18,500 and $25.000 \mathrm{fish} / \mathrm{ha}$ (and 500 cormorant $\mathrm{d} / \mathrm{ha}$ ) were 11 and $14 \%$, respectively (Glahn et al. 2002). Whereas cormorants preferred to forage on pond halves stocked with 49.420 fish/ha than on those stocked with 12,355 fish/ha (and 500 cormorant $d / h a$ ) in the present study, we concur with recommendations of Losinger et al. (2000) regarding the moderate catfish stocking densities $(\sim 17,000-21,000$ fingerlings/ha) associated with profit maximization.

Future research regarding impacts of fish-eating birds on aquacultural production should focus upon the density-dependent (i.e., direct, yet nonlinear) relationships of fish growth and bird foraging behavior. In the context of these impacts, catfish production systems can now be viewed as a function of (1) profit maximization rather than maximum yield (Losinger et al 2000; Pomerleau and Engle 2003), (2) night roost dynamics and pond-specific impacts of cormorants (B. S. Dorr, USDA, Animal and Plant Health Inspection Service, Mississippi, USA. unpublished data), and (3) depredation impacts to gross (i.e., at-harvest) catfish production rather than fingerling replacement costs (Glahn and Dorr 2002; Glahn et al. 2002). Whereas cormorants generally consume catfish that are $12 \mathrm{~cm}$ (Stickley el al. 1992) to $16 \mathrm{~cm}$ (Glahn et al. 1995) in length in the delta region of Mississippi, additional research is needed to evaluate the economic benefits of understocking large catfish fingerlings within grow-out ponds (Engle and Valderrama 2001). Moreover, the success of bird-damage management strategies can be best measured by resultant fish production rather than trends in bird abundance.

\section{Acknowledgments}

The capture, care, and use of study subjects were approved by the Institutional Animal Care and Use Committee of the National Wildlife Research Center. P. Fioranelli, D. T. King, and B. S. Woodruff were instrumental in capturing 
cormorants. We also appreciate the dedicated assistance of P. Fioranelli and B. S. Woodruff during foraging observations, daily animal care, and fish stocking and seining. We are especially grateful to the Mississippi catfish fingerling producer who provided fish for this study. We thank J. F. Glahn, D. T. King, M. E. Tobin, and S. K. Tupper for their thoughtful review of a previous draft of this article.

\section{Literature Cited}

Anderson, C. D., D. D. Roby, and K. Collis. 2004. Foraging patterns of male and female Double-crested Cormorants nesting in the Columbia River cstuary. Canadian Journal of Zoology 82:541-554.

Dirksen, S., T. J. Boudewijn, R. Noordhuis, and E. C. L. Marteijn. 1995. Cormorants Phalacrocorar carbo sinensis in shallow eutrophic freshwater lakes: prey choice and fish consumption in the non-breeding period and effects of large-scale fish removal. Ardea 83:167-184.

Dorr, B., D. T. King, M. E. Tobin, J. B. Harrel, and P. L. Smith. 2004. Double erested cormorant movements in relation to aquaculture in castern Mississippi and western Alabama. Waterbirds 27:147-154.

Engle, C. R. and D. Valderrama. 2001. Effect of stocking density on production characteristics, costs, and risk of producing fingcrling Channei Catfish. North American Journal of Aquaculture 63:201-207.

Glahn, J. F. and K. E. Brugger. 1995. The impact of Double-crested Cormorants on the Mississippi Delta catfish industry: a bioenergetics model. Colonial Waterbirds 18(Special Publication 1): 168-175.

Glahn, J. F. and B. S. Dorr. 2002. Captive Double-crested Cormorant Phalacrocorax auritus predation on Channel Cattish Kcolurtus punctatus fingerlings and its influence on single-butch cropping production. Journal of the World Aquaculture Society 33:85-93.

Glahn, J. F., P. J. Dixon, G. A. Littauer, and R. B. McCoy. 1995. Food habits of Double crested Cormorants wintering in the Delta region of Mississippi. Colonial Warerbirds 18(Special Publication 1):158167.

Glahn, J. F., D. S. Reinhold, and C. A. Sloan. 2000 Recent population trends of Double crested Cormorants wintering in the delta region of Mississippi: responses to roost dispersal and removal under a recent depredation order. Waterbirds 23:38-44.
Glahn, J. F., S. J. Werner, T. Hanson, and C. R. Engle. 2002. Cormorant depredation losses and their prevention at catfish farms: economic considerations. Pages 74-82 in J. Hone, J. A. Shivik, R. A. Watkins, K. C. VerCauteren, and J. K. Yoder. editors. Human Conflicts with Wildlife: Economic Considerations Conference, Fort Collins, Colorado, 1-3 August 2000.

Gremillet, D. and R. P. Wilson. 1999. A life in the fast lane: energetics and foraging strategies of the great cormorant. Behavioral Ecology 10:516-524.

King, D. T., K. J. Andrews, J. O. King, R. D. Flynt, J. F. Glahn, and J. L. Cummings. 1994. A night-lighting technique for capturing cormorants. Journal of Ficld Ornithology 65:254-257.

King, D. T., J. F. Glahn, and K. J. Andrews. 1995. Daily activity budgets and movements of winter roosting Double-crested Cormorants determined hy hiotelemetry in the Delta region of Mississippi. Colonial Waterbirds 18(Special Publication 1): 152-157.

Losinger, W., S. Dasgupta, C. Engle, and B. Wagner. 2000. Econonic interactions between feeding rates and stocking densities in intensive catfish Iclalurus punctatus production. Journal of the World Aquaculture Socicty 31:49」-502.

Pomerleau, S. and C. R. Engle. 2003. Production of stocker-size Channel Catfish: effect of stocking density on production charactcristics, costs, and economic risk. North American Journal of Aquaculture 65:112-119.

Richner, H. 1995. Wintering cormorants Phalacrocorax carbo carbo in the Ythan Estuary, Scotland: numerical and behavioural responses to fluctuating prey availability. Ardea 8.3:19.3-197.

Simmonds, R. L., A. V. Zale, and D. M. Leslie, Jr. 2000. Modeled effects of Double-crested Cormorant predation on simulated reservoir sport and forage fish populations in Oklahoma. North American Journal of Fisheries Management 20:180-191.

Stickley, A. R., G. L. Warrick, and J. F. Glahn. 1992. Impact of double-crested cormorant depredations at channel cattish farms. Journal of the World Aquaculture Society 23:192-198.

Warke, G. M. A. and K. R. Day, 1995. Changes in abundance of cyprinid and percid prey affect rate of predation by cormorants Phalacrocorat carho carto on salmon Salmo salkr smolt in northern Ireland. Ardeal 83:157-166.

Werner, S. J. 2004. Diel foraging behavior of American White Pelicans (Pelecanus erythrorhynchos) on experimental aquaculture ponds. Journal of the World Aquaculture Society 35:513-517. 